\title{
Comparison of the Effects of Organic and Inorganic Selenium on Hatchability of Local Quail
}

\author{
Ahmad Omar Etaki* \\ Production animal dept, Faculty of Agriculture, Aleppo University, Syria \\ *Corresponding author: Ahmad Omar Etaki,Production animal dept, Faculty of Agriculture, Aleppo University, Syria
}

\begin{abstract}
This experiment was conducted to determine the effect of selenium, methionine and different percentages of oil on the hatchability of local quail. A total of 126 nine-months-old quail breeders from local quail were assigned to 7 treatments with 3 replicates of 6 birds each ( 1 male: 5 females). No selenium was added to the control diet, while $0.3 \mathrm{mg} / \mathrm{kg}$ sodium selenite was added to groups of (2-3-4-5), and increased the proportion of (methionine-vitamin E-fat) in the rate of (30-55-40)\% in groups (3-4-5) respectively. Yeast containing organic selenium was added to the 6 th and 7 th group, and the fat was increased $40 \%$ in the seventh group's diet. The results showed that organic selenium has a role in improving hatchability significantly $(\mathrm{p} \leq 0.05)$. Raising the proportion of vitamin E or oil with a large amount in the presence of organic selenium in the diet had a negative effect on hatchability but raising the proportion of methionine in the diet had a positive effect on hatchability.
\end{abstract}

Keywords: Quail, Breeder; Organic selenium; Vitamine E; Methionine; Hatchability

\section{Introduction}

Selenium is an essential nutrient and is important for reducing cell membrane damage. Selenium is found in different forms. Organic forms are found in plant and animal materials and are generally easier for animals to absorb. The feed industry has historically used sodium selenite as an inorganic form of supplementation, but in 2000 the use of organic Se to supplement poultry diets was allowed [1]. Se plays an important role in the maintenance of semen quality which is considered to be an important factor in ensuring the fertility of breeding stock [2]. Se status of the eggs is of great important for the maintenance of the antioxidant system of the developing embryo to increase hatchability. Organic selenium can both improve fertility and more importantly increase duration of fertility [2]. Female chickens have revealed the effectiveness of dietry supplementation with vitamin E, organic selenium or both in sustaining fertility in aging flocks [3]. One of the unique features of avian reproduction is the storage of spermatozoa within an oviducal sperm storage tubular which enables the hen to produce fertile eggs. The existence of complex antioxidant system in the utero-vaginal portion of the fowl oviduct [3].
In particular GSH-Px activity in the utero-vaginal junction was 12-fold higher than in the liver. Improving the antioxidant system of the chick may also enhance immune system function which is extremely important at this point in physiological development embryo. Improving the transfer of Se from the hen's diet by using a Se-yeast instead of sodium selenite is a useful strategy to improve the nutritional status of the embryo as well as that of the newly hatched chick[3]. Methionine supplementation could enhance the production and reproduction performance as well as the antioxidant status and egg quality of broiler breeders[4].

\section{Materials and Methods}

A total of 126 nine-months-old quail breeders from local quail were assigned to 7 treatments with 3 replicates of 6 birds each (1male: 5 females). The breeders were randomly placed in cages (one cage for every replicate). $160 \mathrm{~g}$ of feed offered for every cage daily. The birds were housed in a room at $35^{\circ} \mathrm{C}$. After a month of treatment, egg collection continued for 8 days, during the period of collection of eggs was stored at a temperature of $6^{\circ} \mathrm{C}$ and humidity 
$40 \%$ and stir twice a day and then put eggs in the hatchery to calculate the hatching rate.

\section{Results}

(Tables 1,2) showed that the groups (OSE, SE+MTH, SE+OL) were higher in hatchability than (CO, SE, OSE+OL, SE+VE) groups. The group that fed vitamin E supplementation at $32 \mathrm{mg} / \mathrm{kg}$ showed decreased hatching rate. In the group OSE+OL hatchability reduced to levels close to CO and SE groups. The differences between CO and SE groups were insignificant. SE+MTH group was higher than SE group in hatchability although it contains the same form of selenium and the same concentration of vitamin E. The mortality rate of embryos during the hatching period was highest in CO group and lowest $\mathrm{SE}+\mathrm{OL}$ group with significant difference $(\mathrm{p} \leq 0.05)$. Results show that the increasing in the proportion of methionine in the diet resulted in an increase in the percentage of eggs with grown embryos from the total eggs during the hatching process to the highest level which is significant ( $\mathrm{p} \leq 0.05$ ) with $99.14 \%$, followed by the OSE group with $96.34 \%$. The lowest ratio of eggs with grown embryos was in the SE+VE group. Inorganic selenium did not contribute to an increase in rate of embryo development compared with the $\mathrm{CO}$ group. Adding organic selenium to the diet with oil content to $4 \%$ leads to a decrease in the percentage of the advanced embryos during the hatching process.

Table 1: Shown concentration of methionine, vit $\mathrm{E}$ and lipids for each group of birds in the experiment

\begin{tabular}{|c|c|c|c|c|c|c|c|}
\hline CO & SE & SE+MTH & $S E+V E$ & $\mathrm{SE}+\mathrm{OL}$ & OSE & OSE+OL & \\
\hline $\begin{array}{c}\mathrm{Se} \\
\mathrm{mg} / \mathrm{g}\end{array}$ & $\begin{array}{c}\text { natural } \\
\text { selenium in } \\
\text { diet } \\
0.09\end{array}$ & $\begin{array}{c}\text { added } 0.3 \\
\text { sodium } \\
\text { selenite } \\
0.39\end{array}$ & $\begin{array}{c}\text { added } 0.3 \\
\text { sodium } \\
\text { selenite } \\
0.39\end{array}$ & $\begin{array}{c}\text { added } 0.3 \\
\text { sodium selenite } \\
0.39\end{array}$ & $\begin{array}{c}\text { added } 0.3 \text { sodium } \\
\text { selenite } \\
0.39\end{array}$ & $\begin{array}{c}\text { added } 0.3 \\
\text { organic } \\
\text { selenium } \\
0.39\end{array}$ & $\begin{array}{c}\text { added } 0.3 \text { organic } \\
\text { selenium } \\
0.39\end{array}$ \\
\hline Methionine \% & 0.4 & 0.4 & 0.52 & 0.4 & 0.4 & 0.4 & 0.4 \\
\hline Vit E mg/g & 19.6 & 19.6 & 19.6 & 32 & 27.6 & 19.6 & 27.6 \\
\hline Lipids \% & 3.4 & 3.4 & 3.4 & 3.4 & 4.7 & 3.4 & 4.7 \\
\hline O selenium & - & - & - & - & - & 0.3 & 0.3 \\
\hline
\end{tabular}

Table 2: Total hatchability, the embryonic mortality, the ratio of eggs with grown embryos

\begin{tabular}{|c|c|c|c|c|c|c|c|}
\hline OSE+OL & OSE & $S E+O L$ & $S E+V E$ & SE+MTH & SE & CO & \\
\hline $\mathrm{b}$ & $\mathrm{a}$ & $\mathrm{a}$ & $\mathrm{b}$ & $\mathrm{a}$ & $\mathrm{b}$ & $\mathrm{b}$ & \multirow{3}{*}{ Total Hatchability } \\
\hline 55.35 & 81.5 & 76.15 & 45.61 & 81.36 & 46.8 & 56.81 & \\
\hline \pm 14.9 & \pm 12.1 & \pm 7.1 & \pm 10.5 & \pm 4.6 & \pm 8.7 & \pm 18.1 & \\
\hline $\mathrm{ab}$ & $\mathrm{ab}$ & $\mathrm{a}$ & $a b$ & $a b$ & $\mathrm{ab}$ & $\mathrm{b}$ & \multirow{3}{*}{$\begin{array}{l}\text { The embryonic } \\
\text { mortality rates of } \\
\text { hatcher } \%\end{array}$} \\
\hline 24.15 & 15.68 & 10.12 & 21.38 & 17.92 & 17.32 & 30.15 & \\
\hline \pm 19.6 & \pm 9.5 & \pm 5.9 & \pm 13.7 & \pm 4.3 & \pm 16.4 & \pm 17.1 & \\
\hline c & $\mathrm{ab}$ & $\mathrm{bc}$ & $\mathrm{d}$ & $\mathrm{a}$ & d & c & \multirow{3}{*}{$\begin{array}{l}\text { the ratio of eggs with } \\
\text { grown embryos }\end{array}$} \\
\hline 76.42 & 96.34 & 84.83 & 58.22 & 99.14 & 59.27 & 79.88 & \\
\hline \pm 22.2 & \pm 4.3 & \pm 6.9 & \pm 9.7 & \pm 2.5 & \pm 17.4 & \pm 9.6 & \\
\hline
\end{tabular}

\section{Discussion}

The addition of organic selenium to the diet contributed to increase the fertility of birds, thus obtained the highest hatchability among the groups, this may be due to the role of organic selenium in raising the proportion of antioxidants and fat - soluble vitamins (A-D-E) in the eggs which reflected positively on the rate of embryos that have grown and reduced the mortality rate during the hatching period, but inorganic selenium did not play the same role, similar results in a study were reported by [5]. The increase of methionine to $0.52 \%$ in the diet contributed by providing additional levels of the amino acid for the embryos during the development and perhaps contributed to increasing the absorption of selenium from the gut through the formation of selenomethionine which is absorbed by greater proportions of mineral selenium which has improved the fertility of birds and thus increased the hatchability, similar results obtained with [6]. Increasing the oil content to $4 \%$ in the diet led to higher levels of (A-D-E) vitamins dissolved in the oil, especially with the presence of organic selenium, which contributes to protecting these vitamins from oxidation and thus maintaining their proportions, so these levels of vitamins had a negative impact on the development of the embryos during the hatching process. It decreased the hatchability rate in the OSE + OL group, as was observed in the SE + VE group where the vitamin E concentration in the diet was higher. The SE + OL group did not reduce hatchability to this extent, possibly because the mineral selenium did not contribute to maintaining vitamin levels in eggs as did organic selenium. Therefore, the levels of vitamins in the OSE + OL group were close to that in the SE + VE group, in contrast to the group containing the mineral selenium SE + OL. This research added a comparison of selenium in its organic form with its inorganic form 
on hatching rate as well as mortality ratios that occur during the development of embryos during hatching operations, in addition to the mutual effects between selenium and methionine as an aid in the conversion of mineral selenium to the organic form in the gut of the bird, as well as the mutual effect of selenium with vitamin E, which plays an auxiliary role to selenium in the bird's body and contributes to its absorption, in addition to studying the role of selenium in its form as an antioxidant when raising the percentage of raw fat in the feed mixture[6].

\section{Conclusion}

From the obtained results the addition of organic selenium with $2 \%$ vegetable oil in addition to methionine by $0.52 \%$ to the diet contributes to raising hatchability in the local quail breeders.

\section{References}

1. (2000) Food and Drug Administration FDA approves food additive petition for selenium yeast. FDA Veterinarian Newsletters. DC Food and Drug Administration 10
2. Agate DD, Ơdea EE, Rustad ME (2000) Effects of diatary selenium on laying hen fertility as assessed by the perivielline sperm hole assay. In: Proceedings of the Poultry Research and Production Symposium, Alberta Poultry Research Centre, pp. 1-4.

3. Surai FP, Taylor-Pickard JA (2008) Current advances in selenium research and applications. In: Wageningen Academic Publishers the Netherlands 1: pp. 351.

4. Xue Xiao, Yongxia Wang, Weilong Liu, Tingting Ju, Xiuan Zhan, et al. (2017) Effects of different methionine sources on production and reproduction performance, egg quality and serum biochemical indices of broiler breeders. Asian Australasian Journal of Animal Sciences 30(6): 828-833.

5. Memon A, Ansari NN, Memon 1g, Solangi AA, Qureshi TA, et al. (2003) Effect of Methionine, Lysine and Cystine Supplementation on the Production Performance of Laying Japanese Quails. Journal of Animal and Veterinary Advances 2(1): 27-29.

6. Mohanty PP, Panda N, Swain RK, Behura NC, Ray P, et al. (2018) A Comparison between Organic and Inorganic Selenium: Effect on Body Weight, Laying Performance, Hatchability in Broiler Breeder. International Journal of Current Microbiology and Applied Sciences 7(05): 173-179.

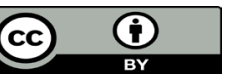

This work is licensed under Creative Commons Attribution 4.0 License

To Submit Your Article Click Here: Submit Article

DOI: $10.32474 /$ CIACR.2020.09.000303

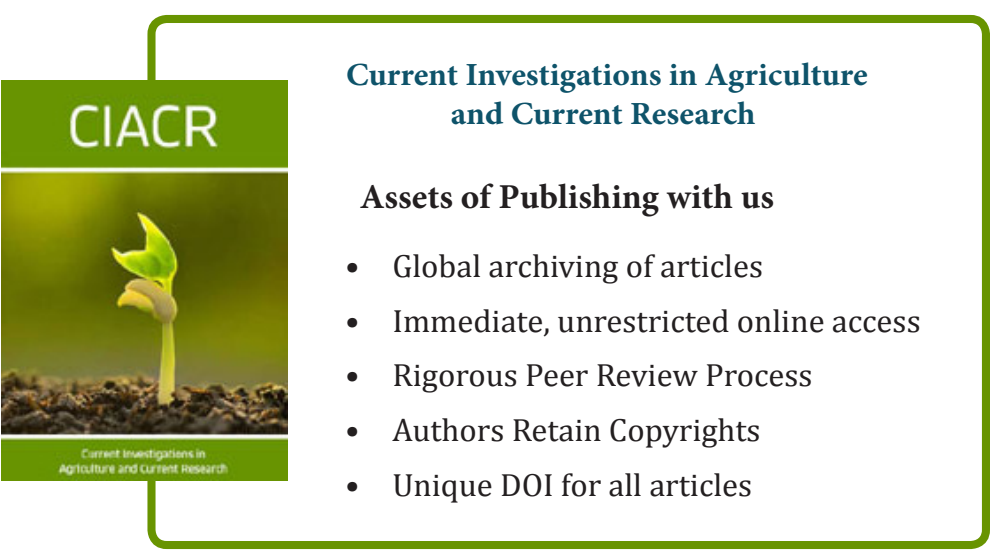

